\title{
Structural Model of Kendeng Basin: A New Concept of Oil and Gas Exploration
}

\author{
Ardian Novianto ${ }^{1,2^{*}}$, Sutanto ${ }^{1}$, Suharsono ${ }^{2}$, Carolus Prasetyadi ${ }^{1}$, Tavip Setiawan ${ }^{3}$ \\ ${ }^{1}$ Geological Engineering Department, UPN “Veteran” Yogyakarta, Yogyakarta, Indonesia \\ ${ }^{2}$ Geophysics Engineering Department, UPN “Veteran” Yogyakarta, Yogyakarta, Indonesia \\ ${ }^{3}$ Research \& Technology Center (RTC) Pertamina, Yogyakarta, Indonesia \\ Email: *ardian.novianto@upnyk.ac.id
}

How to cite this paper: Novianto, A., Sutanto, Suharsono, Prasetyadi, C. and Setiawan, T. (2020) Structural Model of Kendeng Basin: A New Concept of Oil and Gas Exploration. Open Journal of Yangtze Gas and Oil, 5, 200-215.

https://doi.org/10.4236/ojogas.2020.54016

Received: July 28,2020

Accepted: September 5, 2020

Published: September 8, 2020

Copyright $\odot 2020$ by author(s) and Scientific Research Publishing Inc. This work is licensed under the Creative Commons Attribution International License (CC BY 4.0).

http://creativecommons.org/licenses/by/4.0/ (c) (i) Open Access

\begin{abstract}
Kendeng Basin stretches in an E-W direction from the Quaternary Merapi-Ungaran Volcano range in the West to the Madura Strait East of Jawa Timur Province, Indonesia. With Quaternary volcanic deposits covering this basin, its subsurface configuration has not been accurately identified. Several scholars suggest that its configuration forms an asymmetrical basin deepening to the south as a result of volcanic deposits and extending E-W direction. This paper answers what configuration Kendeng Basin has, including whether it consists of a simple asymmetrical shape as previous studies have interpreted or other patterns due to tectonic processes that took place during its formation. The research employed Gravity and Magnetic method, and the results were processed by spectral and gradient analyses. Both analyses revealed that Kendeng Basin formed Horst-Graben structures extending in an $\mathrm{E}-\mathrm{W}$ direction based on a response to compression and strain forces during its formation. A structure with an E-W direction controls the shape of the Horst-Graben and is transected by a structural pattern extending in a NE-SW direction or known as the Meratus pattern. These findings provide an alternative to the concept of oil and gas exploration, which, until today, is merely known from the emergence of oil seepages in Kendeng Basin.
\end{abstract}

\section{Keywords}

Kendeng Basin, Structure, Gravity-Magnetic

\section{Introduction}

Kendeng Basin is one of the basins in the Eastern part of Java Island, Indonesia. It is located in the middle bordered by the Rembang Basin/Sunda Shelf to the North and the Southern Mountain Arc to the south [1] (Figure 1). In this part of 
the island, Kendeng Basin is the main depocenter and is known as a deep basin. With Quaternary volcanic range rising in the south of the basin, its surface is mostly covered by thick young volcanic deposits that pose an enormous challenge to acquiring a comprehensive description of its subterranean geological setting. Accordingly, the configuration of the Kendeng Basin remains unknown.

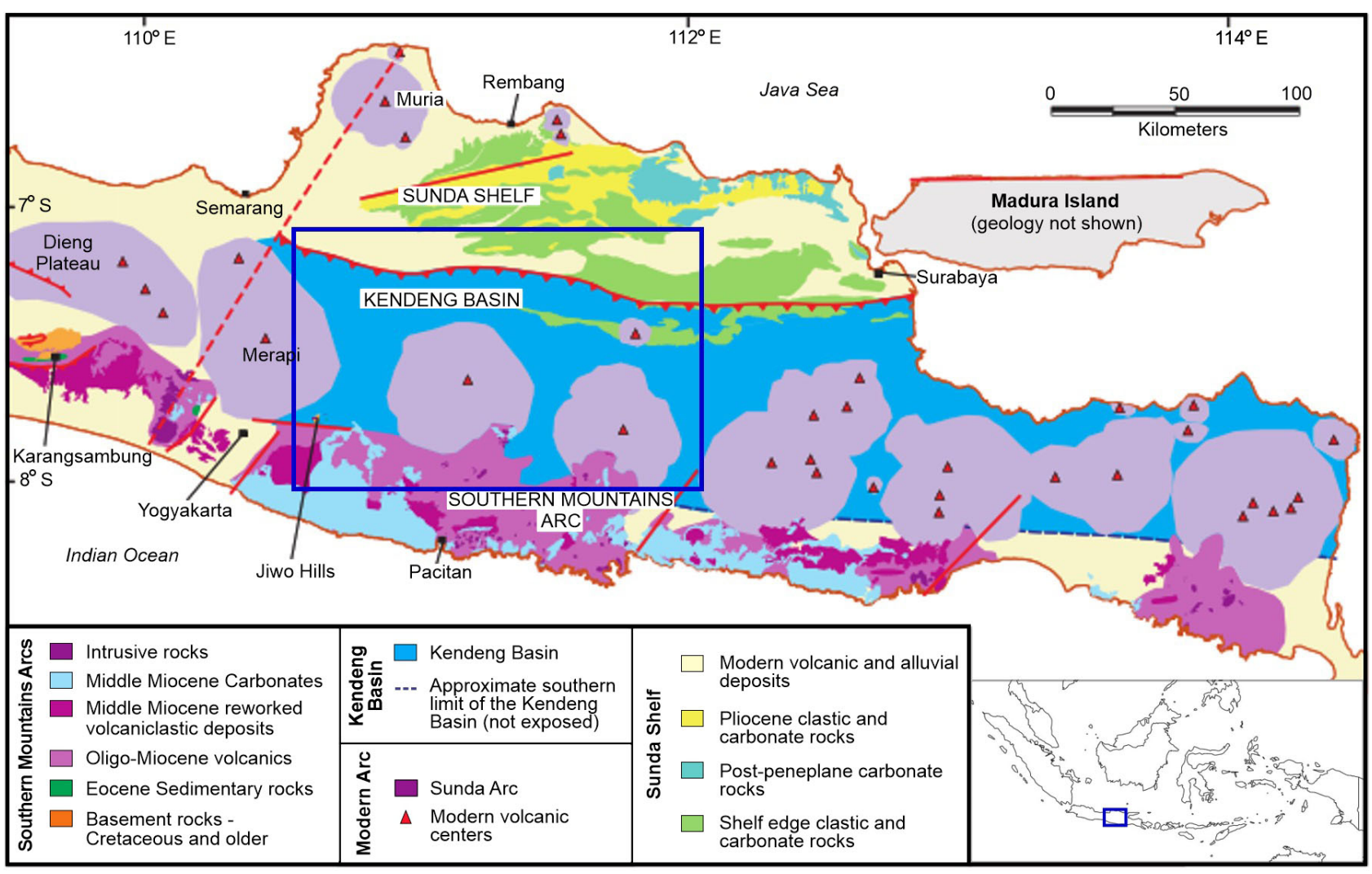

Figure 1. The position of Kendeng Basin in Jawa Timur, Indonesia, which is constrained by the Rembang Basin/Sunda Shelf in the North and in the Southern Mountain Arc in the South [1]. The Blue Box marks the research location.

There has been no oil and gas exploration carried out in the basin because of the thick Quarter volcanic deposits. Potential oil and gas reserves cannot be specified explicitly, although oil reportedly seeps out in several points in the North. The petroleum system, especially relating to source rocks of oil, is yet to be construed because this conceptually flexural basin is filled with volcanic deposits. Without clear evidence that volcanic materials can function as a source rock, a concept of rock deposition as the source rock of oil seepages appearing in the basin must be defined.

Tectonic and basin patterns of Java Island are strongly influenced by plate subduction systems south of the island. Since the middle Cretaceous Period this subduction has changed its direction from NE-SW to E-W due to the collision between the Jawa Timur microcontinent and the south Eastern Sundaland, which significantly influences the resultant structural pattern and basins in Jawa Timur [2]. E-W is a common structural direction found in Jawa Timur that controls the patterns of existing basins, including Kendeng Basin. Due to the 
collision, the structure and configuration of other basins now have a NE-SW direction parallel to the Karangsambung-Meratus pattern. This pattern is visible in the North of Java Island as it forms the horst-graben structures of the KarimuJawa Arc in the West to the Central Deep in the East [3].

These two structural patterns are not clearly expressed in Kendeng Basin, specifically the subterranean structure, due to thick young volcanic deposits covering most of its southern part. The structure responsible for the E-W pattern is expressed as an asymmetrical fold and overthrust formed during the Tertiary, that is, at the end of the tectonic phase [4]. The subsurface condition of the basin has been identified from a large negative pattern of Bouguer gravity anomalies, ranging from $-580 \mu \mathrm{ms}^{-2}$ at the deepest point to approximately $40 \mu \mathrm{ms}^{-2}$ with an increasingly positive pattern Westbound, i.e., around the young volcano Mount Merapi and Dieng Plateau [1]. The basin shows a gravity pattern distributed with a relatively E-W direction that deepens towards the south. The entire pattern of this basin, especially the configuration of its Basement, remains as a never-ending discussion among geologists. However, previous gravity studies have shown that Kendeng Basin is a flexural basin that was formed as a result of loading by volcanic products accumulating in it [5]. Another opinion suggests that the basin pattern determines the shape of the basement. The pattern of the Eastern side of the Jawa Timur basin shows a predominant E-W direction, which forms horst-graben structures. Prior interpretations found that this pattern continues up to Kendeng Basin and controls its configuration [3].

This paper answers the debate about the configuration of the Kendeng Basin by gravity and magnetic methods based on surface measurements. The gravity data combines several measurements performed by the Geological Research and Development Centre, Bandung-Indonesia, and consists of 1500 data measurement points that have been published on gravity anomaly map sheets for Bojonegoro, Madiun, Ngawi, Ponorogo, Salatiga, and Surakarta. Meanwhile, the magnetic data are sourced from 356 points of surface measurement with a distance of $5 \mathrm{~km}$ between them. The Gravity and Magnetic measurement results have been processed by the spectrum/filter analysis and derivatives to identify regional anomalies and their structural patterns. The results of this paper are expected to be able to answer the problem of the Kendeng Basin configuration.

\section{Geological Setting}

\subsection{Tectonic Setting}

The Eastern part of Java was shaped by the interaction between several microcontinents, known collectively as the Argo microcontinent, and the South-East section of Sundaland. This microcontinent moves along the Meso-Tethys subduction path, which has a NE-SW direction and was formed when the subduction of the oceanic Meso-Tethys plate into the Sundaland stopped after the microcontinent collided with the Sundaland in the late Crustaceous-early Paleogene period. This collision changed the direction of the subduction from NE-SW 
to E-W [2] [3], affecting the structural patterns of the basins in Jawa Timur, including Kendeng Basin (Figure 2).

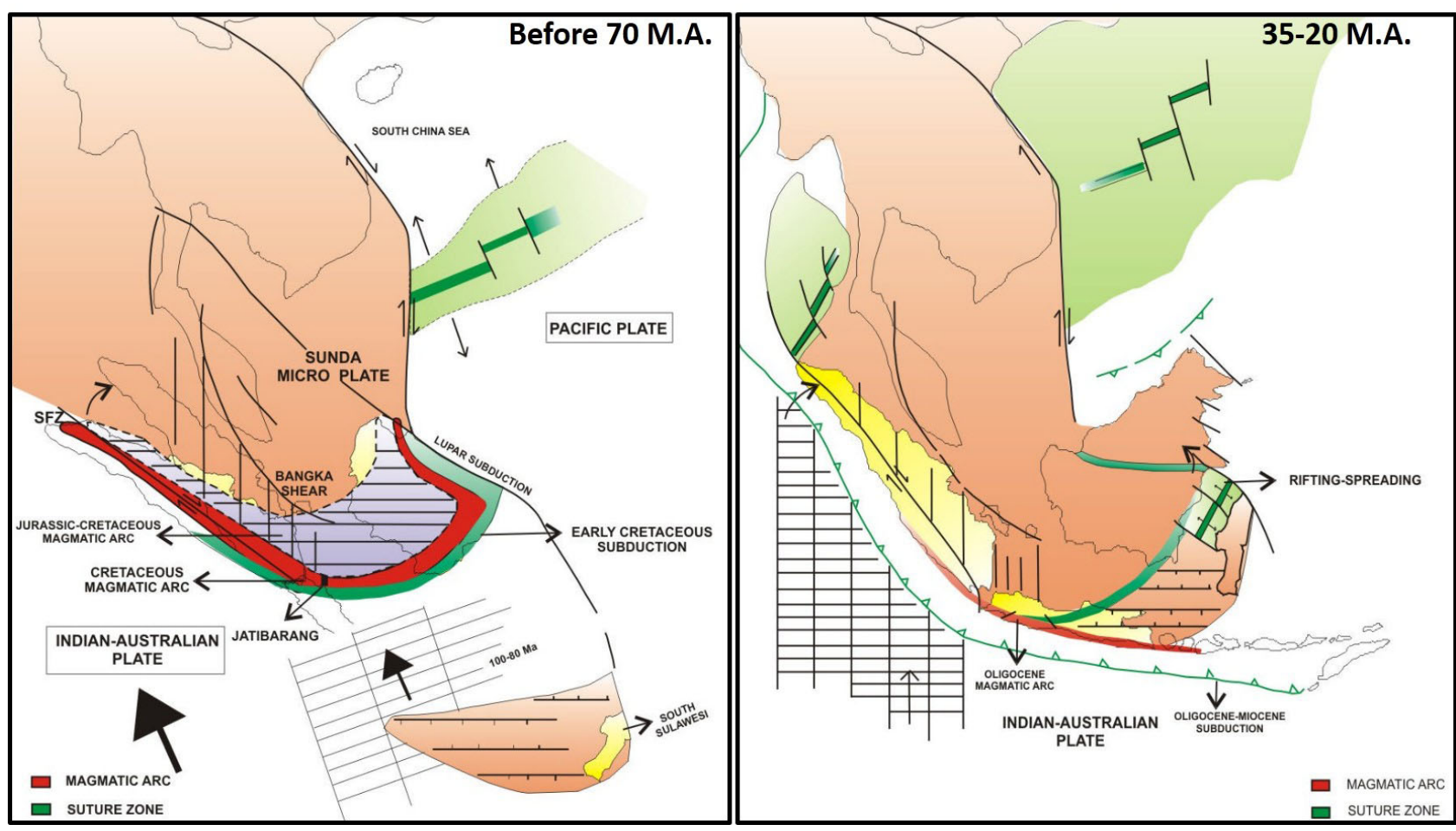

Figure 2. The tectonic development in Eastern Java, which shows the movement of the Jawa Timur microcontinent and its collision with the southeastern part of Sundaland [3].

The NE-SW direction, better known as the Meratus direction, develops mainly in the North of Jawa Timur, which, from the West to the East, comprises Karimunjawa Arch, Muriah Trough, Bawean Arch, Tuban Trough, JS-1 Ridge, and Central Deep. Meanwhile, the E-W direction, or the Java direction, is mostly found in the East of Java Island [3] (Figure 3). How these structures have developed towards the Kendeng Basin is not completely understood owing to the thick young volcanic deposits covering most of the southern part of the basin. No basement in this basin is exposed to the surface or is detectable from the drilling well, due to which the two structures (NE-SW and E-W directions) are challenging to identify. From the surface, the E-W pattern is indicated by the asymmetric Thrust fold pattern in Kendeng Basin, a product of the compression generated by the Neogene subduction of the Indo-Australian plates.

The subsurface condition of Kendeng Basin is assessable from a large negative pattern of Bouguer gravity anomalies, ranging from $-580 \mu \mathrm{ms}^{-2}$ at the deepest point to approximately $40 \mu \mathrm{ms}^{-2}$ with an increasingly positive pattern Westbound, i.e., around the young volcano Mount Merapi and Dieng Plateau [1]. Accordingly, the basin shows asymmetric basin pattern deepening to the south, approaching the quaternary volcanic range with a relatively long E-W axis (Figure 4 ). 


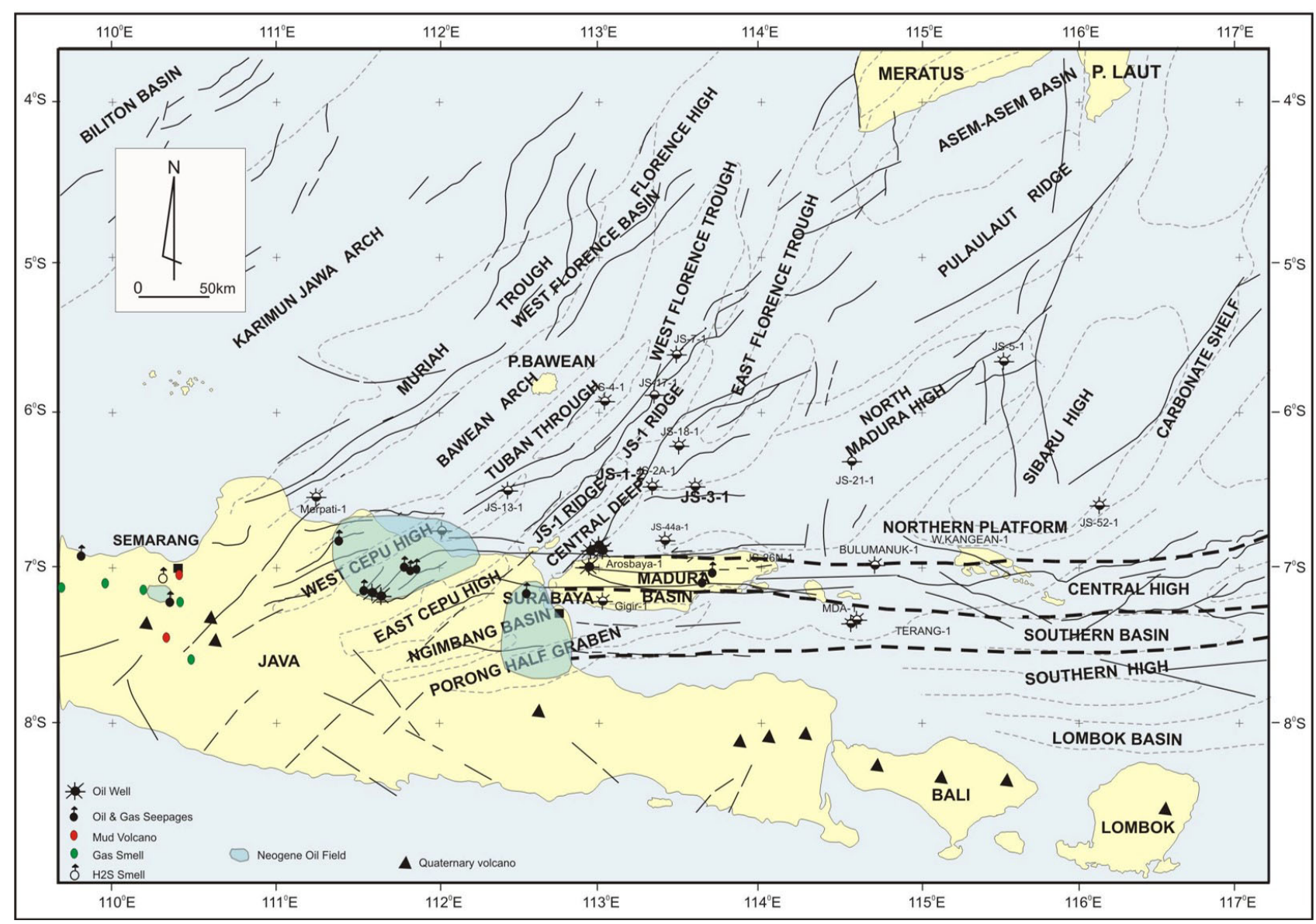

Figure 3. The tectonic elements of Jawa Timur indicate structures in NE-SW direction (developed mainly in the north of Java) and $\mathrm{E}-\mathrm{W}$ direction (identified in the east of Jawa Timur) [3].

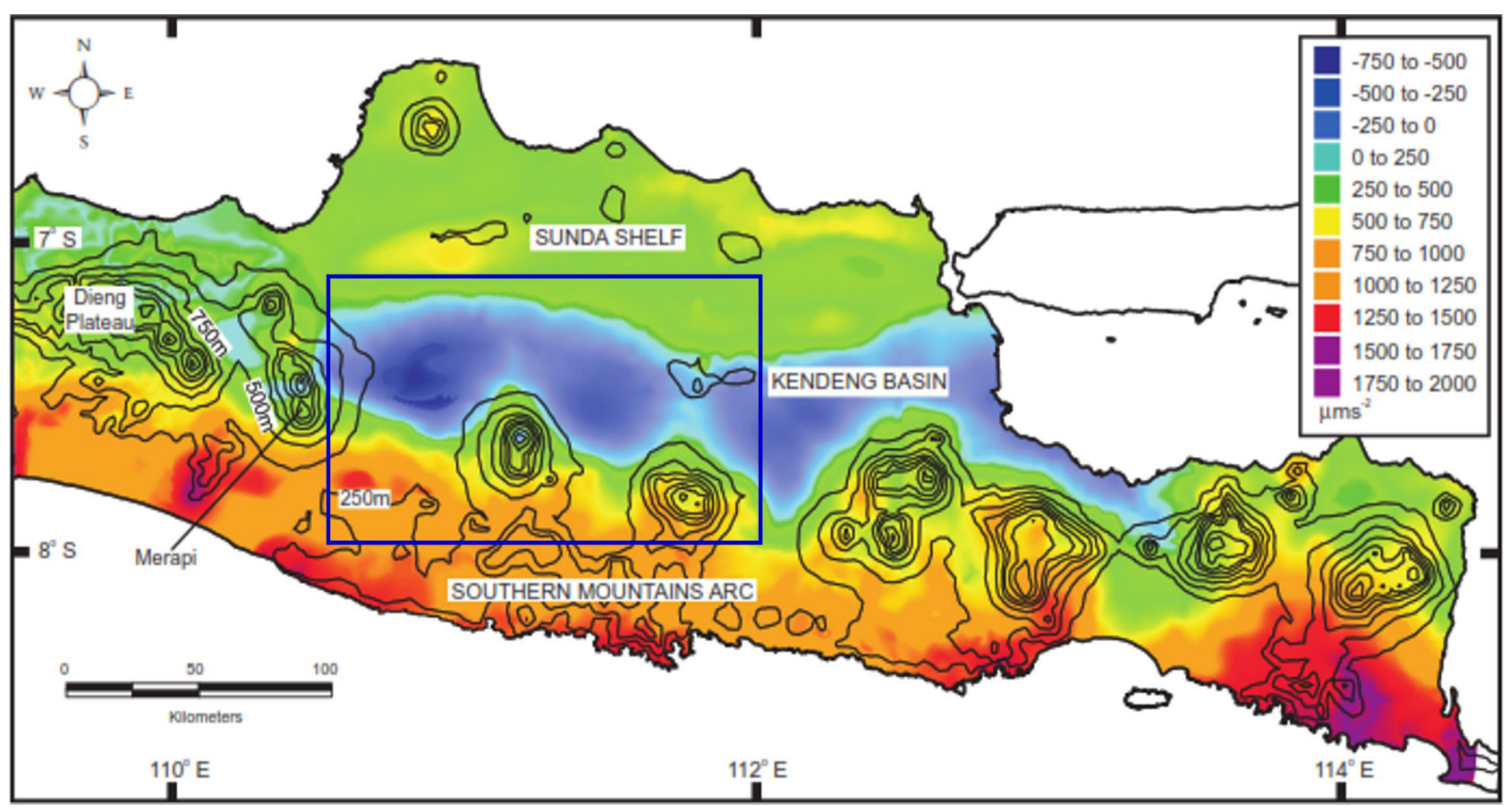

Figure 4. The Bouguer gravity anomaly of Kendeng Basin [1]. 


\subsection{The Concept of Kendeng Basin}

The interpretation of the Kendeng Basin's pattern based on the Bouguer Gravity anomaly gave rise to a number of opinions relating to its basement properties. The asymmetrical shape of the basin, with an inner axis approaching the volcanic belt, is interpreted as a result of loading by active volcanic products in the south of Java starting from the Middle Eocene until the Quaternary Volcanic [5] [6]. The accumulation of volcanic materials increases pressure and temperature, leading to crustal densification. Volcanic activities contribute to the formation of basins through loading, plate weakening due to volcanic arcs, or the combination thereof. The volcanic products that accumulate during the formation of the Kendeng basin will compensate for the local isostatic and regional lithospheric flexural in the Kendeng Basin, making it known as the Flexural Basin [5] [7] (Figure 5). In a flexural basin, the tilt angle is the main controller for the deposition of synorogenic sediments into the basin. According to this concept, volcanic deposits growing in the south have been filling the basin since the Middle Eocene.

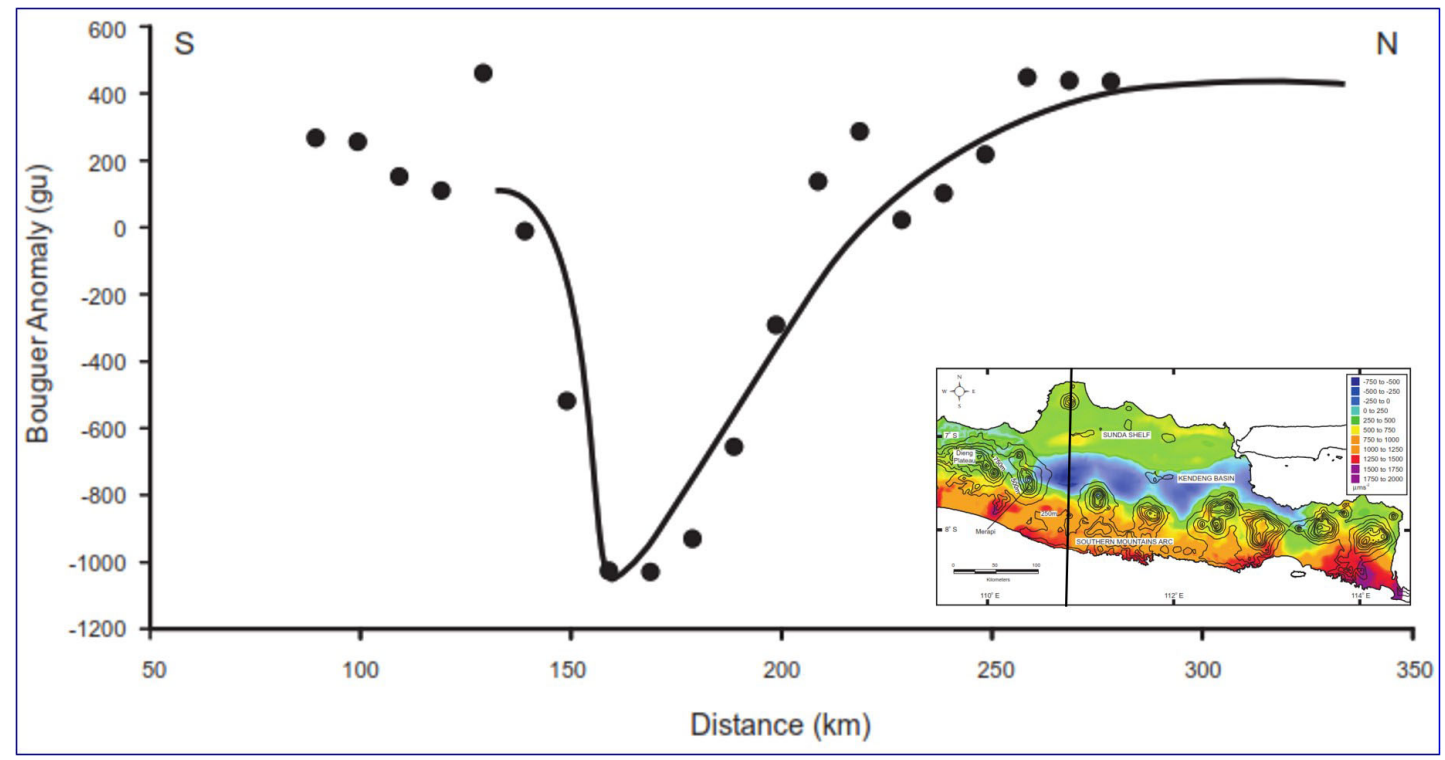

Figure 5. The plotting of Bouguer anomalies in a North-South direction traversing the Kendeng Basin shows a flexural basin with deep asymmetric basin pattern towards the South as a result of volcanic loading [5].

The character of the flexural basin as identified from the Gravity data $[5,1]$, shows different configurations with the surrounding basins. For instance, the Rembang Basin in the North has been well identified using seismic data and drilling wells. Seismic data extending from Karimunjawa Arc to Randugunting Trough and Purwodadi High describe its configuration on the West and define the configuration of the basement as a horst-graben, which is a Paleogene structure that controls the inside deposition of rocks and supports the overlying Neogene structure [8] (Figure 6(A)). Rembang Basin is a proven oil and gas-producing basin with Eocene syn-rifting deposits from the Ngimbang and Pre-Ngimbang Formations as the source rock [9]. The formation deposits are identified based on drilling data, which are distributed along the Meratus trend (NE-SW direction) 


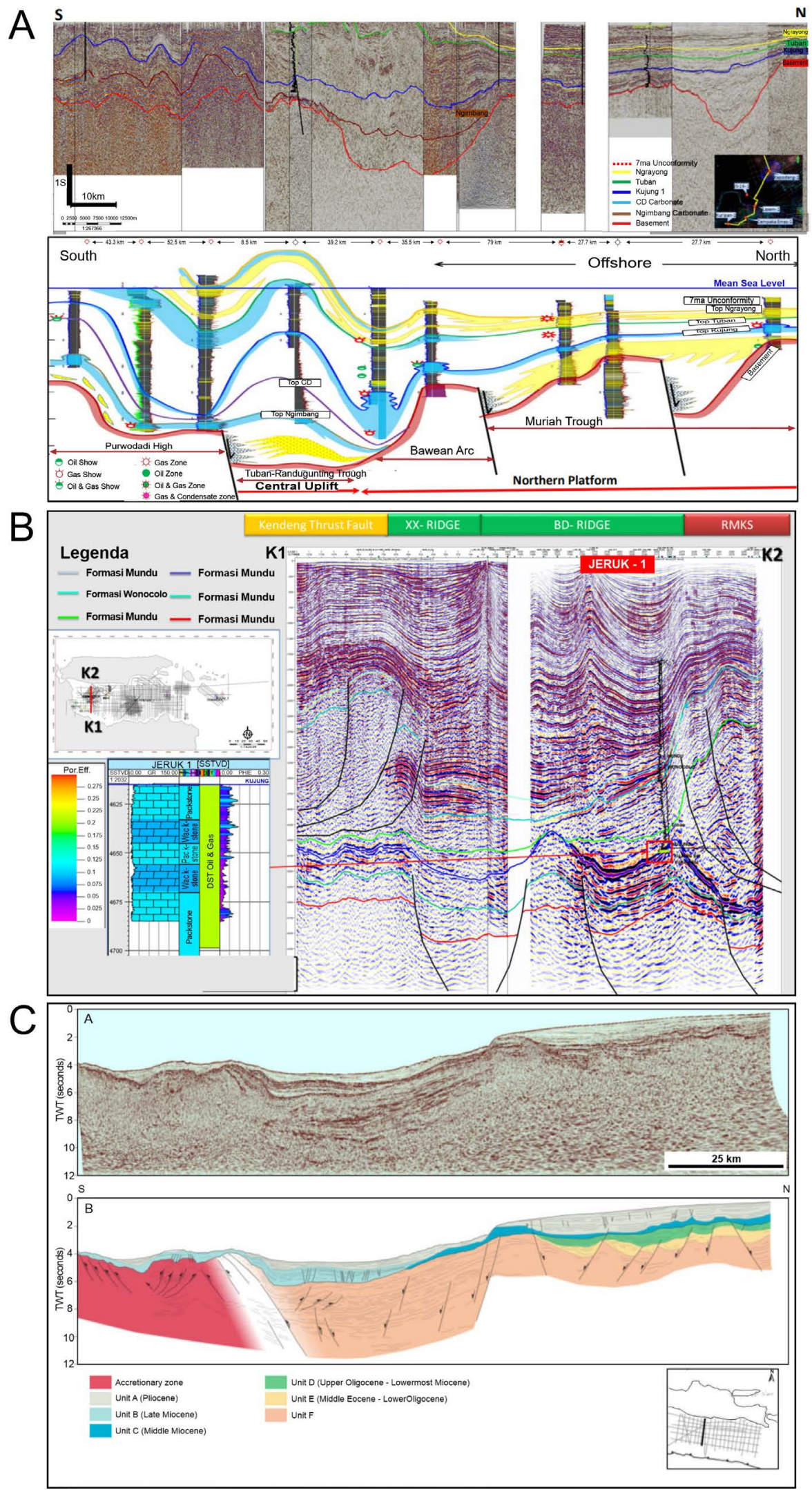

Figure 6. The configurations of the surrounding basins show a pattern of Horst-Graben. (A) Rembang Basin [8], (B) The Madura Strait East of Kendeng Basin [10], and (C) Jawa Timur Forearc [11]. 
and a graben extending with an E-W direction. Seismic data indicates the presence of deposits with strong reflections known as Pre-Ngimbang deposits, which lie unconformably beneath the Ngimbang Formation. The data collected from the wells that penetrate the Pre-Ngimbang Formation and have an E-W distribution support this evidence, confirming local Paleo Highs as the continental source from the Cretaceous to Eocene [3].

In Jawa Timur, which is the continuity of Kendeng Basin, the Horst-Graben pattern is seen in the seismic data of the south of Madura Island [10]. These data further show that the Paleogene Horst-Graben structures underlying the Thrust Fault are in fact a transitional zone between Kendeng and Rembang Basins (Figure 6(B)). This horst-graben is still visible in the seismic data of the Java forearc [11] (Figure 6(C)).

The basement configuration around the Kendeng Basin, which presents a Horst-Graben pattern in E-W and NE-SW directions, is the result of a history of convergent tectonics in the south of Java from early Crustaceous to Eocene. Kendeng Basin may also have this structural pattern, but the accumulation of thick volcanic deposits poses a particular challenge to its identification attempts. Gravity data that presents how the asymmetric Kendeng Basin is tilted to the south as compensation for volcanic loading need to be re-analyzed. The facts about the basement configuration in its surroundings must be considered, particularly in discussing the tectonic concept occurring in this basin.

\section{Methods}

This research employed potential-field methods to characterize the configuration of the Kendeng Basin, namely Gravity and Magnetic. Both methods are extensively used at various scales, for example, in the delineation of basins at regional scales to accommodate detailed investigation of a prospect. They were selected due to the subterranean geological condition of the basin, i.e., extensive thick volcanic deposits. For the same reason, the use of other methods such as seismic to sense the subsurface condition is infeasible. Gravity and Magnetic can record variations in rock density and susceptibility up to the crust layer, and as a result, volcanic deposits found at shallow depths in the field do not preclude their ability to detect more buried geological features. Each potential-field method was used to distinguish the shape of the rocks with different densities and susceptibilities based on the combined gravity and magnetic anomalies. The results of the Gravity and Magnetic methods were combined to determine the structural patterns and the subterranean pattern of the basin.

Data processing to describe the configuration of the basin was carried out in several stages, namely correction of field measurements, spectrum analysis to filter frequencies, and application of derivatives to clarify geological structures with no apparent Gravity and Magnetic anomalies. The flow diagram of the research methods can be seen in Figure 7.

The gravity and magnetic anomalies measured on the surface are the sums of all possible sources of anomalies existing beneath the surface, one of which is the 


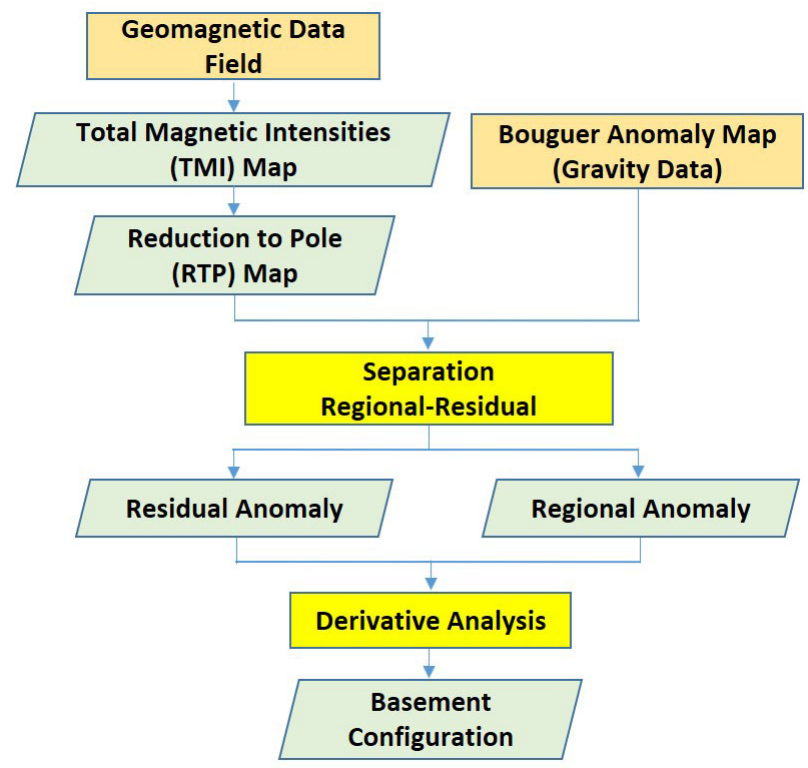

Figure 7. The research flow diagram using the Potential-Field Methods (Gravity and Magnetic).

target event of exploration. During the interpretation process, the target event must be separated from other targets. If the target event is a regional anomaly, then the other targets are residual anomalies and noise. Simply, in terms of width, the noise has a narrower anomaly than residual targets, and regional anomalies are wider than the residual. Meanwhile, based on depth, noise is shallower than residual anomalies, and the regional is deeper than the residual.

Residual and regional anomalies can be separated in various ways, including filtering by spectrum analysis. Filtering was intended to separate anomalies based on frequencies, which represent the depth of the source of anomalies. Residual anomalies are associated with high frequencies, whereas regional anomalies with low frequencies. Hence, the filtering process was aimed to detect regional anomaly representative of actual subsurface conditions [12]. Spectrum analysis that was performed following the Fourier transform was the process of changing the shape of a signal to the sum of several sinusoidal signals or series with various frequencies. This transform changes the signals that were previously in the time domain into the frequency domain. In other words, through this transformation, the depth of the data can be estimated. The Fourier transform produces amplitude spectrum and phase spectrum. Regional and residual anomaly separation used the separation of wavenumber $(\mathrm{k})$ and amplitude $(\mathrm{A})$ to calculate the width of the filter window as a parameter of the filtering process. The results of the Fourier transform can be mathematically formulated as follows:

$$
A=C e^{|k|\left(Z_{0}-Z^{\prime}\right)}
$$

where $A$ is the amplitude, $C$ is a constant, $k$ is the wavenumber, $Z_{0}$ is the elevation of observation points, and $Z^{\prime}$ is the depth of anomalous objects. The relationship between amplitude $(A)$, wavenumber $(k)$, and depth $\left(Z_{0}-Z^{\prime}\right)$ can be 
written as follows:

$$
\operatorname{Ln} A=\left(Z_{0}-Z^{\prime}\right)|k|
$$

where the depth of the boundary between regional anomaly, residual, and noise is indicated by the gradient of each graph of the regional, residual, and noise zones (Figure 8).

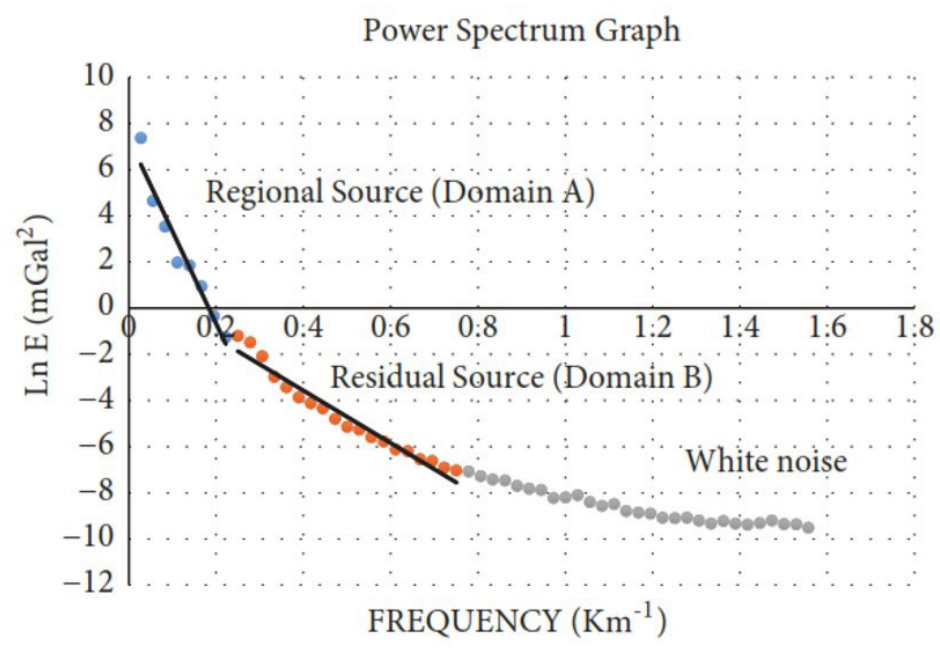

Figure 8. Illustration of how to determine the Regional-Residual of anomalies based on the regression analysis of the Fourier Transform results [12].

Gradient calculations can improve the fine features of potential-field data that are not visually visible in the field data. Increased values of the boundaries between anomalous objects are expected to appear after the application of horizontal and vertical gradients [13] [14]. Spatial derivatives of the field data are usually analyzed for qualitative and semi-quantitative interpretation. High gradients are associated with highly contrasting physical properties of subsurface anomalies and vice versa. Gradients, and their magnitude, are generally used to describe the boundaries of the sources of subsurface anomalies. In the Fourier domain (wavenumber), Second Vertical Derivative (SVD) can be calculated using the equation below:

$$
\frac{\partial^{2} g_{2}}{\partial z^{2}}=F^{-1}\left(|k|^{2} G_{z}\right) \text { with }|k|^{2}=k_{x}^{2}+k_{y}^{2}
$$

where $G_{z}$ is the Fourier transform of $G_{z}, k_{x}$ and $k_{y}$ are the wavenumbers on the $x$ and $y$ axes, respectively, and $F^{-1}$ is the inverse operator of the Fourier transform. Derivative processes will increase the high frequency contained in the data (Equation (3)) so that the map derived from the potential-field data looks as if it contains a significant amount of noise when compared to the original data [15].

\section{Result and Discussion}

The Jawa Timur Basin, including Kendeng Basin, is located on the southEastern side of Sundaland, which is a part of the Eurasian Continent. The subduction 
and collision processes occurring throughout the tectonic history in southern Java produced several structural patterns that control the basins in the area. The collision between the Jawa Timur microcontinent and Sundaland formed NE-SW structural patterns (known as the Meratus pattern) in the North of the Java Sea. This pattern is estimated to extend southbound to Kendeng Basin [3]. This convergence was followed by divergence (rifting) that produced a series of half-grabens deposits framed by up-thrown ridges with a NE-SW direction along the suture zone.

Reactivated tectonics due to changes in the direction of subduction from NE-SW to E-W induced a compression force that caused major inversion in the basin and wrenching with an E-W direction. This wrenching, which is situated in the North of Kendeng Basin, is indicated by an East-West strike-slip fault, commonly known as the RMKS (Rembang-Madura-Kangean-Sakala) fault. This pattern is a reactivated graben structure that generated the formation of an inversion structure found on Madura Island. In Jawa Timur, the onshore structure with an E-W direction is clearly reflected in the fold direction and overthrust in Kendeng Basin.

The previous gravity analysis results, Figure 4, showed a basin pattern with a relative E-W direction, which was interpreted as a pattern formed during the Neogene due to the formation of the Back Arc Basin. Also, they might not describe structural patterns that illustrate the tectonic response during the Paleogene. The gravity and magnetic data acquired in the field were analyzed as an effort to describe the Paleogene structure affecting the formation of the Kendeng Basin. The analysis started with separating regional from residual anomalies in the data by spectrum analysis to obtain the low and high frequencies. Interpretations revealed that the basin has a depth of $8-11 \mathrm{Km}$ [1], meaning that a low frequency (regional anomaly) must be used to be able to acquire this depth information and analyze the structural pattern.

The regional anomalies sorted out of the gravity data, as presented in Figure 9, had significantly different characters from the Bouguer anomaly. Bouguer anomaly is a mixture of regional and residual anomalies, enabling further analysis that can characterize a basin. These regional anomalies showed an E-W structural pattern in Kendeng Basin that is responsible for the current Horst-Grabens pattern and is believed to be the original structural pattern, i.e., an old structure activated during the collision between the Jawa Timur microcontinent and Sundaland. This E-W structural pattern is transected by a structure with a NE-SW direction, forming two alignments in the West (i.e., Bayat-Kening Through-Tuban Through structure) and East (the Ponorogo-Central Deep alignment). The Gravity Analysis results are supported by the Regional Magnetic analysis, which showed the same pattern of regional gravity anomalies (Figure 10).

The field data were also processed by horizontal and vertical Gradient/Derivative analyses, which are expected to clarify the boundary of the sources of anomaly caused by faults developing in the Kendeng Basin. High gradients can be interpreted as high contrasting physical properties below the surface, and vice versa, which are geologically associated with changes in physical properties due to 


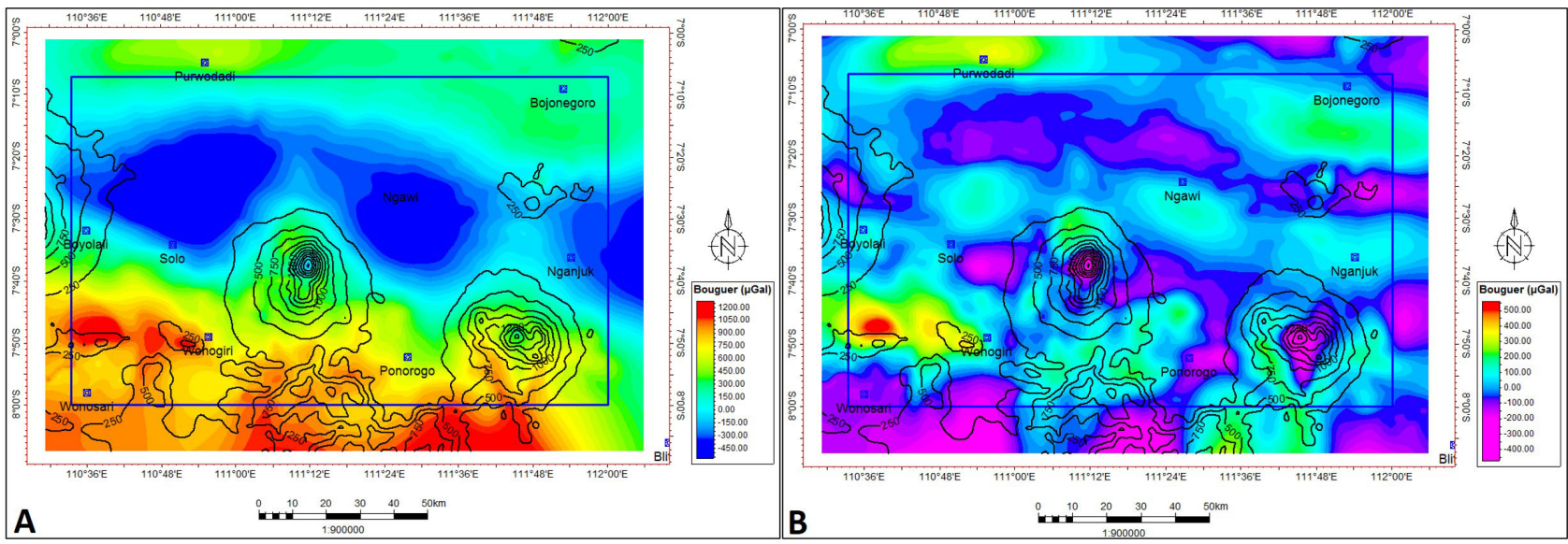

Figure 9. The configuration of the Kendeng Basin in the research area. (A) Basin configuration based on the Bouguer anomalies presented in Smyth (2008) [1]. (B) Basin configuration based on the separation of the regional anomalies (showing a pattern of Horst-Grabens).

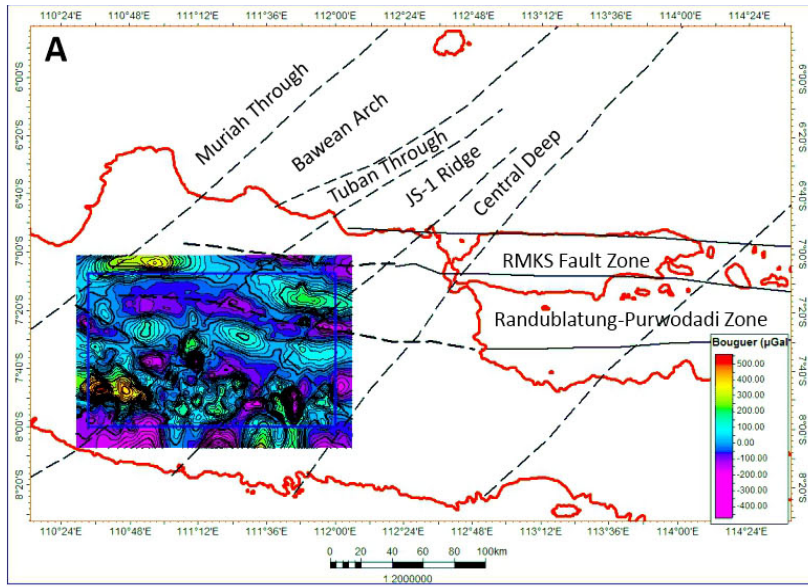

\section{C}
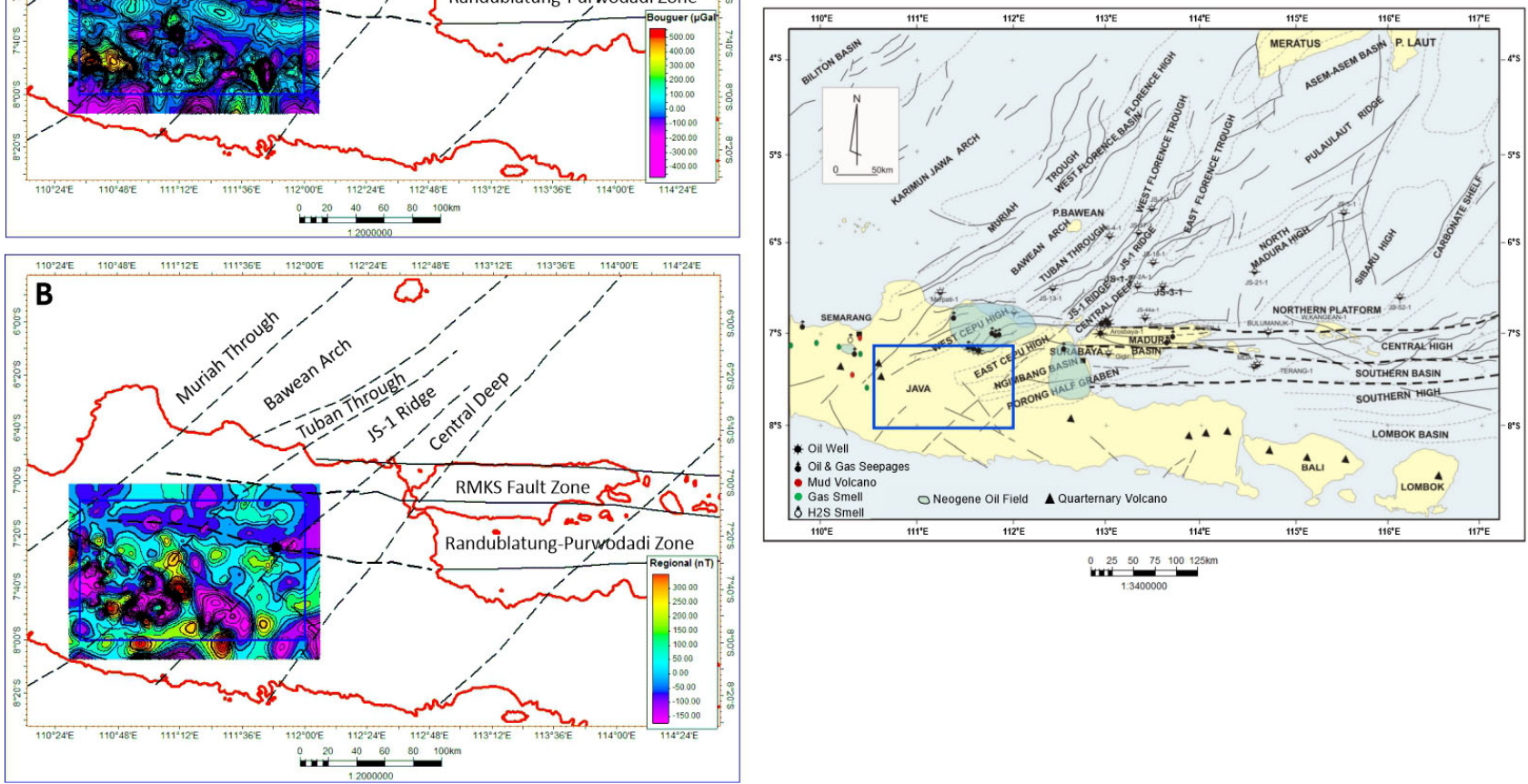

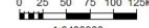

Figure 10. The regional structure of the Kendeng Basin, based on the Regional Gravity Anomaly (A) and Magnetic Analyses (B), shows structural patterns in E-W and NE-SW directions similar to the regional structure of Java presented in Sribudiani (2003) [3] (C).

faults. The derivative was performed based on the Horizontal Gradient Magnitude (HGM) and Second Vertical Derivative (SVD) analyses, as well as the Bott's criteria to analyze the structural pattern according to the predetermined $1 \mathrm{D}$ 
path. The Bott's criteria perceive negative gravity anomalies from the relative magnitude of SVD or $\left|g^{\prime}\right|$ along the profile. If $\left|g_{\max }^{\prime \prime}\right|$ is greater than $\left|g_{\min }^{\prime \prime}\right|$, then the anomaly is associated with a sedimentary basin with an inward sloping edge. On the contrary, if $\left|g_{\max }^{\prime \prime}\right|$ is smaller than $\left|g_{\min }^{\prime \prime}\right|$, then the source of the anomaly is granite plutons with an outward sloping edge [15]. Based on these criteria, the $\mathrm{N}-\mathrm{S}$ cross-sections were made along the study area for structural analysis (Figure 11).

The structural derivative analysis revealed the direction of the faults developing in the basement. This direction is a fault pattern identified as a result of tectonic compression during the Plio-Pleistocene, which, according to Figure 11, is also responsible for the reverse faults in the Kendeng Basin. The cross-sections show faults with a south-trending sloping pattern as a compensation for the compression force from the south due to the subduction in southern Java. The $1 \mathrm{D}$ cross-sections can be interpreted horizontally based on a combination of several 1D cross-sections.

Southern

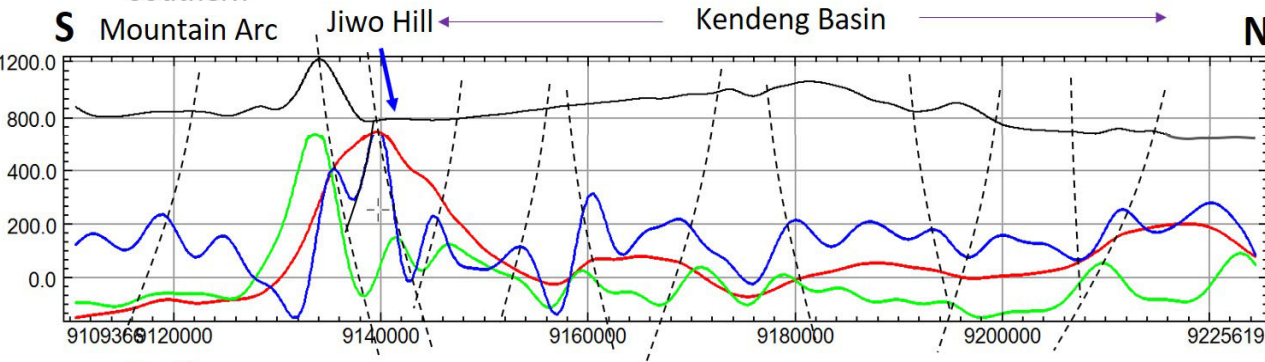

Southern

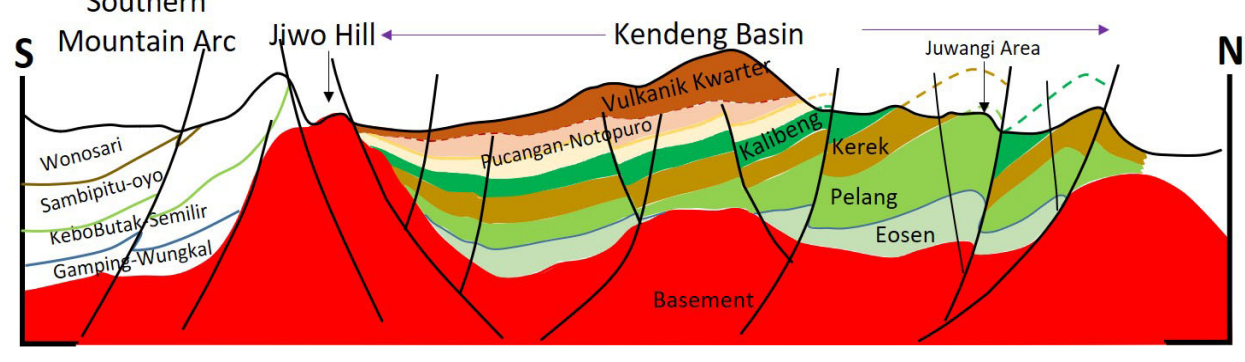

N Topography Map

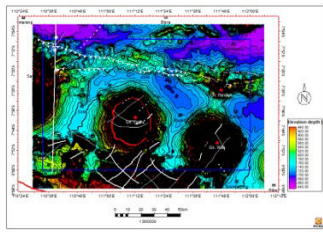

Regional Gravity Horizontal Derivative Vertical Derivative

N Topography Fault Interpretation

Figure 11. Interpretation of structures based on derivative analysis (HGM, SVD) along the 1D trajectory, which revealed that the direction of the fault was formed by tectonics in the Kendeng Basin.

The configuration of the Kendeng Basin (Figure 12), which shows a Horst-Graben pattern, has the same character as the surrounding basins. If this configuration is assumed to have formed due to tectonic activities and at the same time as the surrounding basins, then the syn-rifting rock deposits are likely equivalent to the Pre-Ngimbang and Ngimbang deposits in the Rembang Basin or the constituent rocks of the Gamping-Wungkal Formation in the Southern Mountains. There has been no evidence from rock outcrops or drilling wells on Eocene syn-rifting deposits in Kendeng Basin. The oldest rock identified from these outcrops in Juwangi Area is the Pelang Formation, which was formed during the early Miocene. Syn-rifting deposits may have been identified from rock fragments carried by mud-volcano in Sangiran Dome, with the same characteristics as the 
Gamping-Wungkal Formation in the Southern Mountains [16]. This indication brings new hope for the source rock of oil seepage in the Kendeng Basin. This expectation indirectly supports the Geochemical Analysis of oil seepage and rocks, which revealed that the source of the oil seepage is rock older than the Pelang Formation [17] [18]. This rock probably originated in Eocene syn-rifting deposits in the Kendeng Basin.

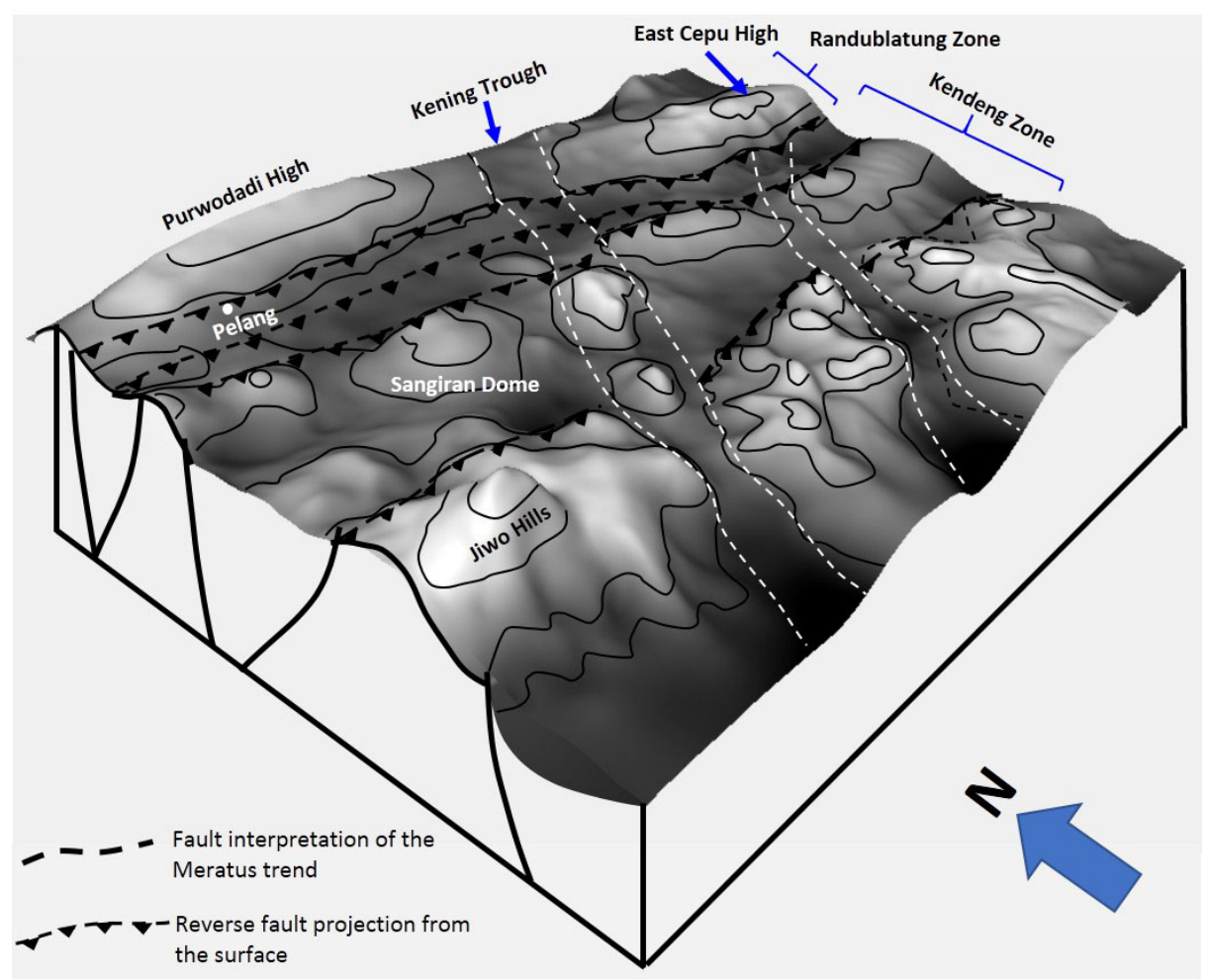

Figure 12. The configuration of the Kendeng basin in a 3D block model, which shows E-W and NE-SW horst-graben structures.

\section{Conclusions}

1) The configuration of the Kendeng Basin, as interpreted from the Bouguer Gravity Anomaly, shows a flexural basin pattern formed during the Neogene.

2) As identified from the regional Magnetic and Gravity anomalies, this configuration forms Horst-Graben structures with an E-W direction.

3) Based on the derivative analysis results, the Horst-Graben structures are controlled by an E-W Normal Fault and were reactivated during the Plio-Pleistocene compression.

4) The structural pattern with an E-W direction is transected by a NE-SW structure due to the collision between the Jawa Timur microcontinent and Sundaland.

5) The Horst-Graben configuration of the Kendeng Basin has similarities with the basement patterns in the Rembang Basin and the Southern Mountains that are filled with Eocene sediments, which are proven as the source rocks of oil in the Rembang Basin. 


\section{Acknowledgements}

The authors thank Geological Research and Development Centre (Geological Survey Center), for publishing accessible data. The authors also thank Pertamina Research Technology Center (RTC) for input and discussion during the study.

\section{Conflicts of Interest}

The authors declare no conflicts of interest regarding the publication of this paper.

\section{References}

[1] Smyth, H.R., Hall, R. and Nichols, G.J. (2008) Cenozoic Volcanic Arc History of East Java, Indonesia: The Stratigraphic Record of Eruptions on an Active Continental Margin. The Geological Society of America, 436, 199-222. https://doi.org/10.1130/2008.2436(10)

[2] Satyana, A.H. (2016) The Emergence of Pre-Cenozoic Petroleum System in East Java Basin: Constraints from New Data and Interpretation of Tectonic Reconstruction, Deep Seismic, and Geochemistry. Proceedings of Indonesian Petroleum Association Fortieth Annual Convention \& Exhibition, 25-27 May 2016, IPA16-573-G. https://doi.org/10.29118/ipa.0.16.573.g

[3] Sribudiyani, Muchsin, N., Ryacudu, R., Kunto, T., Astono, P., Prasetya, I., Sapiie, B., Asikin, S., Harsolumakso, A.H. and Yulianto, I. (2003) The Collision of the East Java Microplate and Its Implication for Hydrocarbon Occurrences in the East Java Basin. Proceedings of Indonesian Petroleum Association, Jakarta, 14-16 October 2003, IPA03-G-085. https://doi.org/10.29118/ipa.1530.03.g.085

[4] Prasetyadi, C. (2007) Evolusi Tektonik Paleogene Jawa Bagian Timur. Bandung Technology Institute, Bandung, Indonesia. https://scholar.google.co.id/citations?user=y5MS85EAAAAJ\&hl=id

[5] Waltham, D., Hall, R., Smyth, H.R. and Ebinger, C.J. (2008) Basin Formation by Volcanic Arc Loading. The Geological Society of America, 436, 11-26. https://doi.org/10.1130/2008.2436(02)

[6] Smyth, H., Hall, R., Hamilton, J. and Kinny, P. (2005) East Java: Cenozoic Basins, Volcanoes and Ancient Basement. 30 th Annual Convention of the Indonesian Petroleum Association, Jakarta, August 30-September 1 2005, IPA05-G-045. https://doi.org/10.29118/ipa.629.05.g.045

[7] Allen, P.A. and Allen, J.R. (2005) Basin Analysis, Principles and Applications. Blackwell Publishing, Hoboken.

[8] Juliansyah, M.N., Mazied, M. and Arisandy, M. (2016) Regional Stratigraphic Correlation across the East Java Basin: Integrated Application of Seismic, Well, Outcrop and Biostratigraphic Data. Proceedings Indonesian Petroleum Association Fortieth Annual Convention \& Exhibition, Jakarta, 25-27 May 2016, IPA16-510-G. https://doi.org/10.29118/ipa.0.16.510.g

[9] Satyana, A.H. (2015) Subvolcanic Hydrocarbon Prospectivity of Java: Opportunities and Challenges. Proceedings Indonesian Petroleum Association, 39 th Annual Annual Convention and Exhibition, Jakarta, 20-22 May 2015, IPA15-G-105. https://doi.org/10.29118/ipa.0.15.g.105

[10] Prasetyadi, C., Rachman, M.G., Hapsoro, S.E., Shirly, A., Gunawan, A. and Purwaman, I. (2016) Seismic-Based Structural Mapping of RMKS Fault Zone: Implication to Hydrocarbon Accumulation in East Java Basin. Proceedings Geosea XIV and 
45th IAGI Annual Convention, Bandung, Indonesia, 10-13 October 2016.

http://repo-nkm.batan.go.id/1088/1/PROSIDING_SUKADANA_PTBGN_2016.pdf

[11] Nugraha, A.S. and Hall, R. (2012) Cenozoic History of the East Java Forearc. Proceedings Indonesian Petroleum Association, 36th Annual Convention \& Exhibition, Jakarta, 23-25 May 2012, IPA12-G-028. https://doi.org/10.29118/ipa.0.12.g.028

[12] Nguiya, S., Lemotio W., Nouck, P.N., Pemi, M.M., Tokam, A.-P.K. and Ngatchou, E. (2019) 3D Mafic Topography of the Transition Zone between the North-Western Boundary of the Congo Craton and the Kribi-Campo Sedimentary Basin from Gravity Inversion. International Journal of Geophysics, 2019, Article ID: 7982562. https://doi.org/10.1155/2019/7982562

[13] Tsuboi, C. (1983) Gravity. George Allen \& Unwin Ltd., London.

[14] Telford, W.M., Geldart, L.P. and Sheriff, R.E. (1990) Applied Geophysics. 2nd Edition, Cambridge University Press, Cambridge. https://doi.org/10.1017/CBO9781139167932

[15] Sumintadireja, P., Dahrin, D. and Grandis, H. (2018) A Note on the Use of the Second Vertical Derivative (SVD) of Gravity Data with Reference to Indonesian Cases. Journal Engineering Technology, 50, 127-139. https://doi.org/10.5614/j.eng.technol.sci.2018.50.1.9

[16] Itihara, M., Sudijono, W., Kadar, D., et al. (1985) Geology and Stratigraphy of the Sangiran Area. Geological Research and Development Center library, Bandung, Indonesia.

[17] Ramadhan, B., Maha, M., Hapsoro, S.E., Budiman, A. and Fardiansyah, I. (2015) Unravel Kendeng Petroleum System Enigma: Recent Update from Transect Surface Observation of Kedungjati-Djuwangi-Ngawi Area, East Java. Proceedings, Indonesian Petroleum Association 39th Annual Convention \& Exhibition, Jakarta, 20-22 May 2015, IPA15-SG-065. https://doi.org/10.29118/ipa.0.15.sg.065

[18] Pramono, W. and Amijaya, H. (2008) Geochemical Characteristic of Oil Seepage in Bantal Area, Semarang, Central Java. Proceedings Indonesian Association of Geologists (IAGI), Indonesia. http://repository.ugm.ac.id/digitasi/index.php?module=cari_hasil_full\&idbuku=324 $\underline{3}$ 